U.S. Geological Survey Mineral Resources Program, prepared in cooperation with

Bureau of Reclamation, Bureau of Land Management, and Utah Department of Environmental Quality Division of Water Quality

\title{
Results of Mineral, Chemical, and Sulfate Isotopic Analyses of Water, Soil, Rocks, and Soil Extracts from the Pariette Draw Watershed, Uinta Basin, Utah
}

Open-File Report 2015-1132 



\section{Results of Mineral, Chemical, and Sulfate Isotopic Analyses of Water, Soil, Rocks, and Soil Extracts from the Pariette Draw Watershed, Uinta Basin, Utah}

By Jean M. Morrison, Michele L.W. Tuttle, and Juli W. Fahy

U.S. Geological Survey Mineral Resources Program, prepared in cooperation with

Bureau of Reclamation, Bureau of Land Management, and Utah Department of

Environmental Quality Division of Water Quality

Open-File Report 2015-1132 


\title{
U.S. Department of the Interior SALLY JEWELL, Secretary
}

\section{U.S. Geological Survey Suzette M. Kimball, Acting Director}

\author{
U.S. Geological Survey, Reston, Virginia: 2015
}

For more information on the USGS - the Federal source for science about the Earth, its natural and living resources, natural hazards, and the environment—visit http://www.usgs.gov or call 1-888-ASK-USGS.

For an overview of USGS information products, including maps, imagery, and publications, visit http://www.usgs.gov/pubprod/.

Any use of trade, firm, or product names is for descriptive purposes only and does not imply endorsement by the U.S. Government.

Although this information product, for the most part, is in the public domain, it also may contain copyrighted materials as noted in the text. Permission to reproduce copyrighted items must be secured from the copyright owner.

Suggested citation:

Morrison, J.M., Tuttle, M.L.W., and Fahy, J.W., 2015, Results of mineral, chemical, and sulfate isotopic analyses of water, soil, rocks, and soil extracts from the Pariette Draw Watershed, Uinta Basin, Utah: U.S. Geological Survey Open-File Report 2015-1132, 10 p., http://dx.doi.org/10.3133/ofr20151132.

ISSN 2331-1258 (online) 


\section{Contents}

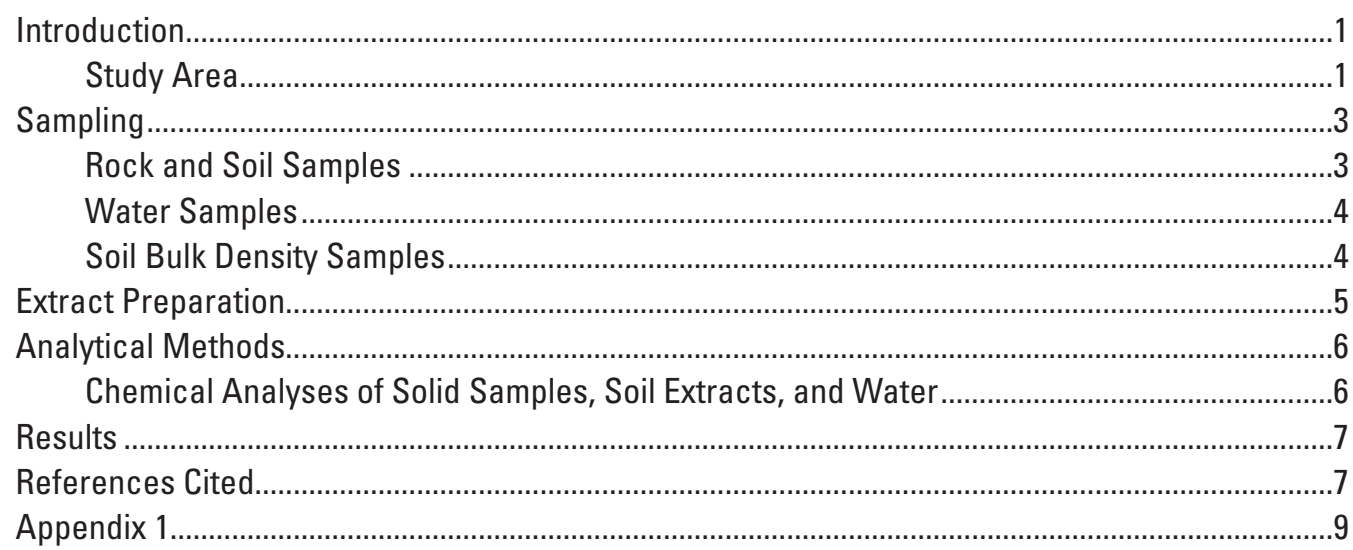

\section{Figures}

1. Location map for the Pariette Draw Watershed ..................................................................

2. Simplified geologic map for the Pariette Draw Watershed ....................................................3

3. Map of rock and soil collection sites with $A$, showing entire watershed

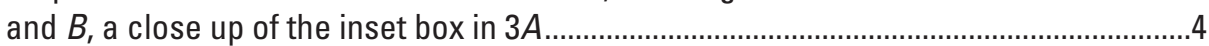

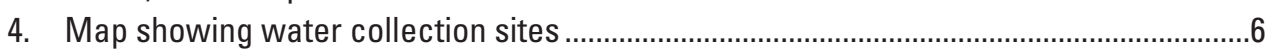

\section{Tables}

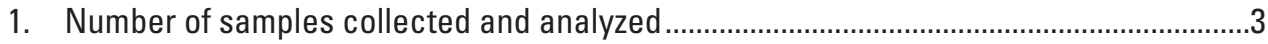

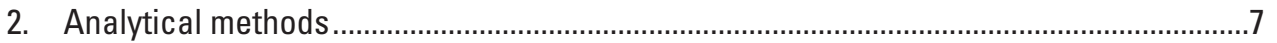

\section{Appendix Tables}

(Available at http://dx.doi.org/10.3133/ofr20151132)

1-1. Sample site designation, location, and description

1-2. Water chemical data

1-3. Rock mineralogical data

1-4. Rock chemical data

1-5. Bulk soil density data

1-6. Soil mineralogical data

1-7. Bulk soil chemistry

1-8. Bulk rock and soil chemistry (selected samples and selected elements by sodium peroxide sinter ICP-MS)

1-9. Soil extract chemistry

1-10. Water analysis metadata

1-11. Rock analysis metadata

1-12. Bulk soil metadata

1-13. Soil extract metadata

1-14. Sulfate Isotope metadata 


\section{Conversion Factors}

Inch/Pound to SI

\begin{tabular}{|c|c|c|}
\hline Multiply & By & To obtain \\
\hline \multicolumn{3}{|c|}{ Length } \\
\hline inch (in.) & 2.54 & centimeter $(\mathrm{cm})$ \\
\hline foot $(\mathrm{ft})$ & 0.3048 & meter (m) \\
\hline mile (mi) & 1.609 & kilometer $(\mathrm{km})$ \\
\hline \multicolumn{3}{|c|}{ Area } \\
\hline acre & 0.004047 & square kilometer $\left(\mathrm{km}^{2}\right)$ \\
\hline square mile $\left(\mathrm{mi}^{2}\right)$ & 2.590 & square kilometer $\left(\mathrm{km}^{2}\right)$ \\
\hline \multicolumn{3}{|c|}{ Volume } \\
\hline gallon (gal) & 3.785 & liter (L) \\
\hline gallon (gal) & 0.003785 & cubic meter $\left(\mathrm{m}^{3}\right)$ \\
\hline \multicolumn{3}{|c|}{ Mass } \\
\hline ounce, avoirdupois (oz) & 28.35 & $\operatorname{gram}(\mathrm{g})$ \\
\hline pound, avoirdupois (lb) & 0.4536 & kilogram (kg) \\
\hline \multicolumn{3}{|c|}{ Density } \\
\hline pound per cubic foot $\left(\mathrm{lb} / \mathrm{ft}^{3}\right)$ & 0.01602 & gram per cubic centimeter $\left(\mathrm{g} / \mathrm{cm}^{3}\right)$ \\
\hline
\end{tabular}

SI to Inch/Pound

\begin{tabular}{|c|c|c|}
\hline Multiply & By & To obtain \\
\hline \multicolumn{3}{|c|}{ Length } \\
\hline centimeter $(\mathrm{cm})$ & 0.3937 & inch (in.) \\
\hline meter (m) & 3.281 & foot $(\mathrm{ft})$ \\
\hline kilometer $(\mathrm{km})$ & 0.6214 & mile (mi) \\
\hline \multicolumn{3}{|c|}{ Area } \\
\hline square kilometer $\left(\mathrm{km}^{2}\right)$ & 247.1 & acre \\
\hline square kilometer $\left(\mathrm{km}^{2}\right)$ & 0.3861 & square mile $\left(\mathrm{mi}^{2}\right)$ \\
\hline \multicolumn{3}{|c|}{ Volume } \\
\hline liter $(\mathrm{L})$ & 0.2642 & gallon (gal) \\
\hline cubic meter $\left(\mathrm{m}^{3}\right)$ & 0.0002642 & million gallons (Mgal) \\
\hline cubic hectometer $\left(\mathrm{hm}^{3}\right)$ & 810.7 & acre-foot (acre-ft) \\
\hline \multicolumn{3}{|c|}{ Mass } \\
\hline $\operatorname{gram}(\mathrm{g})$ & 0.03527 & ounce, avoirdupois (oz) \\
\hline kilogram $(\mathrm{kg})$ & 2.205 & pound avoirdupois (lb) \\
\hline \multicolumn{3}{|c|}{ Density } \\
\hline gram per cubic centimeter $\left(\mathrm{g} / \mathrm{cm}^{3}\right)$ & 62.4220 & pound per cubic foot $\left(\mathrm{lb} / \mathrm{ft}^{3}\right)$ \\
\hline
\end{tabular}

Temperature in degrees Celsius $\left({ }^{\circ} \mathrm{C}\right)$ may be converted to degrees Fahrenheit $\left({ }^{\circ} \mathrm{F}\right)$ as follows:

$$
{ }^{\circ} \mathrm{F}=\left(1.8 x^{\circ} \mathrm{C}\right)+32
$$

Temperature in degrees Fahrenheit $\left({ }^{\circ} \mathrm{F}\right)$ may be converted to degrees Celsius $\left({ }^{\circ} \mathrm{C}\right)$ as follows:

$$
{ }^{\circ} \mathrm{C}=\left({ }^{\circ} \mathrm{F}-32\right) / 1.8
$$

Vertical coordinate information is referenced to the North American Vertical Datum of 1988 (NAVD 88).

Horizontal coordinate information is referenced to the North American Datum of 1983 (NAD 83).

Specific conductance is given in millisiemens per centimeter at 25 degrees Celsius $(\mu \mathrm{S} / \mathrm{cm}$ at $\left.25^{\circ} \mathrm{C}\right)$.

Concentrations of chemical constituents in water are given either in milligrams per liter $\left(\mathrm{mg} / \mathrm{L}^{-1}\right)$ or micrograms per liter $\left(\mu \mathrm{g} / \mathrm{L}^{-1}\right)$. 


\section{Abbreviated Chemical Symbols}

\begin{tabular}{|c|c|}
\hline Abbreviation & Chemical species \\
\hline $\mathrm{Ag}$ & silver \\
\hline $\mathrm{Al}$ & aluminum \\
\hline As & arsenic \\
\hline B & boron \\
\hline $\mathrm{Ba}$ & barium \\
\hline $\mathrm{Be}$ & beryllium \\
\hline $\mathrm{Bi}$ & bismuth \\
\hline $\mathrm{Br}$ & bromine \\
\hline $\mathrm{C}_{\text {total }}$ & total carbon \\
\hline $\mathrm{C}_{\mathrm{CO} 3}$ & carbonate carbon \\
\hline $\mathrm{C}_{\mathrm{org}}$ & organic carbon \\
\hline $\mathrm{Ca}$ & calcium \\
\hline $\mathrm{Cd}$ & cadmium \\
\hline $\mathrm{Ce}$ & cerium \\
\hline $\mathrm{Cl}$ & chlorine \\
\hline Co & cobalt \\
\hline $\mathrm{Cr}$ & chromium \\
\hline Cs & cesium \\
\hline $\mathrm{Cu}$ & copper \\
\hline DOC & dissolved organic carbon \\
\hline Dy & dysprosium \\
\hline Er & erbium \\
\hline $\mathrm{Eu}$ & europium \\
\hline $\mathrm{Fe}$ & iron \\
\hline $\mathrm{Ga}$ & gallium \\
\hline $\mathrm{Gd}$ & gadolinium \\
\hline $\mathrm{Ge}$ & germanium \\
\hline $\mathrm{HCO}_{3}$ & Bicarbonate \\
\hline $\mathrm{Hg}$ & mercury \\
\hline Ho & holmium \\
\hline In & indium \\
\hline $\mathrm{K}$ & potassium \\
\hline $\mathrm{La}$ & lanthanum \\
\hline $\mathrm{Li}$ & lithium \\
\hline $\mathrm{Lu}$ & lutetium \\
\hline $\mathrm{Mg}$ & magnesium \\
\hline $\mathrm{Mn}$ & manganese \\
\hline Mo & molybdenum \\
\hline $\mathrm{N}$ & nitrogen (as N) \\
\hline $\mathrm{Na}$ & sodium \\
\hline $\mathrm{Nb}$ & niobium \\
\hline $\mathrm{Nd}$ & neodymium \\
\hline $\mathrm{Ni}$ & nickel \\
\hline $\mathrm{NO}_{3}$ & nitrate \\
\hline $\mathrm{O}_{\mathrm{SO} 4}$ & sulfate oxygen \\
\hline $\mathrm{P}$ & phosphorous \\
\hline $\mathrm{Pb}$ & lead \\
\hline $\operatorname{Pr}$ & prasceodmium \\
\hline $\mathrm{Rb}$ & rubidium \\
\hline $\mathrm{S}$ & sulfur \\
\hline
\end{tabular}




\section{Abbreviated Chemical Symbols-Continued}

\begin{tabular}{cl}
\hline Abbreviation & Chemical species \\
\hline $\mathrm{S}_{\mathrm{SO}}$ & sulfate sulfur \\
$\mathrm{Sb}$ & antimony \\
$\mathrm{Sc}$ & scandium \\
$\mathrm{Se}$ & selenium \\
$\mathrm{Sm}$ & samarium \\
$\mathrm{Sn}$ & tin \\
$\mathrm{SO}_{4}$ & sulfate \\
$\mathrm{Sr}$ & strontium \\
$\mathrm{Ta}$ & tantalum \\
$\mathrm{Tb}$ & terbium \\
$\mathrm{Te}$ & tellurium \\
$\mathrm{Th}$ & thorium \\
$\mathrm{Ti}$ & titanium \\
$\mathrm{Tl}$ & thallium \\
$\mathrm{Tm}$ & thulium \\
$\mathrm{U}$ & uranium \\
$\mathrm{V}$ & vanadium \\
$\mathrm{W}$ & tungsten \\
$\mathrm{Y}$ & yttrium \\
$\mathrm{Zn}$ & zinc \\
$\mathrm{Zr}$ & zirconium \\
\hline
\end{tabular}




\section{Acknowledgments}

The authors wish to thank all the people who contributed to the Pariette Draw study.

Darren Williams (Bureau of Land Management, Vernal office), Sandy Wingert (Utah Department

of Environmental Quality, Division of Water Quality), Colleen Jones and Astrid Jacobson (Utah

State University), and Evan Guymon (Uintah Basin Watershed Coordinator) helped identify

sampling areas, provided field support, helped collect samples, and (or) shared their expertise of the Pariette Draw watershed and Pariette Wetlands. We also want to thank the Pleasant Valley landowners who granted permission to sample their agricultural fields. Funding of this project was through the U.S. Geological Survey Mineral Resources Program, the Bureau of Reclamation Colorado River Salinity Control Program, the Bureau of Land Management Salinity Program, and the Utah Department of Environmental Quality Nonpoint Source Project. 



\title{
Results of Mineral, Chemical, and Sulfate Isotopic Analyses of Water, Soil, Rocks, and Soil Extracts from the Pariette Draw Watershed, Uinta Basin, Utah
}

\author{
By Jean M. Morrison, Michele L.W. Tuttle, and Juli W. Fahy
}

\section{Introduction}

In 2010, Utah Department of Environmental Quality (DEQ) Division of Water Quality (UDWQ, 2010) determined that water quality in Pariette Draw was in violation of Federal and State water quality criteria for total dissolved solids (TDS), selenium (Se), and boron (B). The measure of total dissolved solids is the sum of all the major ion concentrations in solution and in this case, the dominant ions are sodium (Na) and sulfate $\left(\mathrm{SO}_{4}\right)$, which can form salts like thenardite $\left(\mathrm{Na}_{2} \mathrm{SO}_{4}\right)$ and mirabilite $\left(\mathrm{Na}_{2} \mathrm{SO}_{4} \cdot \mathrm{H}_{2} \mathrm{O}\right)$. The Utah Department of Environmental Quality (2010) classified the contamination as natural background and from nonpoint sources related to regional lithology and irrigation practices. Although the daily loads of the constituents of concern and water chemistry have been characterized for parts of the watershed, little is known about the controls that bedrock and soil mineralogy have on salt, Se, and B storage and the water-rock interactions that influence the mobility of these components in ground and surface waters. Studies in the Uncompahgre River watershed in Colorado by Tuttle and others (2014a, 2014b) show that salt derived from weathering of shale in a semiarid climate is stored in a variety of minerals that contribute solutes to runoff and surface waters based on a complex set of conditions such as water availability, geomorphic position (for example, topography controls the depth of salt accumulation in soils), water-table fluctuations, redox conditions, mineral dissolution kinetics, ion-exchange reactions, and secondary mineral formation. Elements like Se and B commonly reside in soluble salt phases, so knowledge of the behavior of salt minerals also sheds light on the behavior of associated contaminants.

The goal of this study was to establish a process-based understanding of salt, Se, and B behavior to address whether these contaminants can be better managed, or if uncontrollable natural processes will overwhelm any attempts to bring Pariette Draw into compliance with respect to recently established total maximum daily limits (TMDLs). We collected data to refine our knowledge about the role of rock weathering and soil formation in the transport and storage of salt in the watershed and to show how salt is cycled under irrigated and natural conditions. Our approach was to sample rock, soils, and sediment on irrigated and natural terrain for mineralogical analysis to determine the residence of salt and associated Se and $\mathrm{B}$, classify minerals as primary (related to rock formation) or secondary weathering products, and characterize mineral dissolution kinetics. Mineral and chemical analyses and selective extractions of rocks and soils provide useful information in understanding solute movement and mineral dissolution/ formation. The resulting data are critical in determining residence of salt, Se, and B in weathered rock and soil and understanding the mobility during water-rock-soil interactions. This report summarizes our methods for sample and data collection and tabulates the mineral, chemical, and isotopic data collected.

\section{Study Area}

The Pariette Draw watershed (hydrologic unit code (HUC) \#14060005) is 316 square miles $\left(\mathrm{mi}^{2}\right)$ and is located in the Uinta Basin, northeastern Utah (Duchesne and Uintah Counties and the Uintah and Ouray Indian Reservation; fig. 1). The watershed is south of the city of Myton and is bordered by the Duchesne River (north), Tavaputs Plateau (south and west) and the Green River (east; Utah Department of Environmental Quality, 2010). Agriculture composes 4.2 percent of the land cover in the watershed and the remaining is primarily native inter-mountain basin shale badlands with extensive oil and gas development (Utah Department of Environmental Quality, 2010). Landownership is as follows: 68 percent Bureau of Land Management (BLM), 12 percent private, 9 percent School and Institutional Trust Lands Administration (SITLA), 7 percent tribal, and 4 percent U.S. Forest Service (Utah Department of Environmental Quality, 2010).

Pariette Draw is a tributary to the Green River and is perennial only because of irrigation in Pleasant Valley where agriculture occurs. All tributary drainages into Pariette Draw are ephemeral. Irrigation runoff provides water to Pariette 


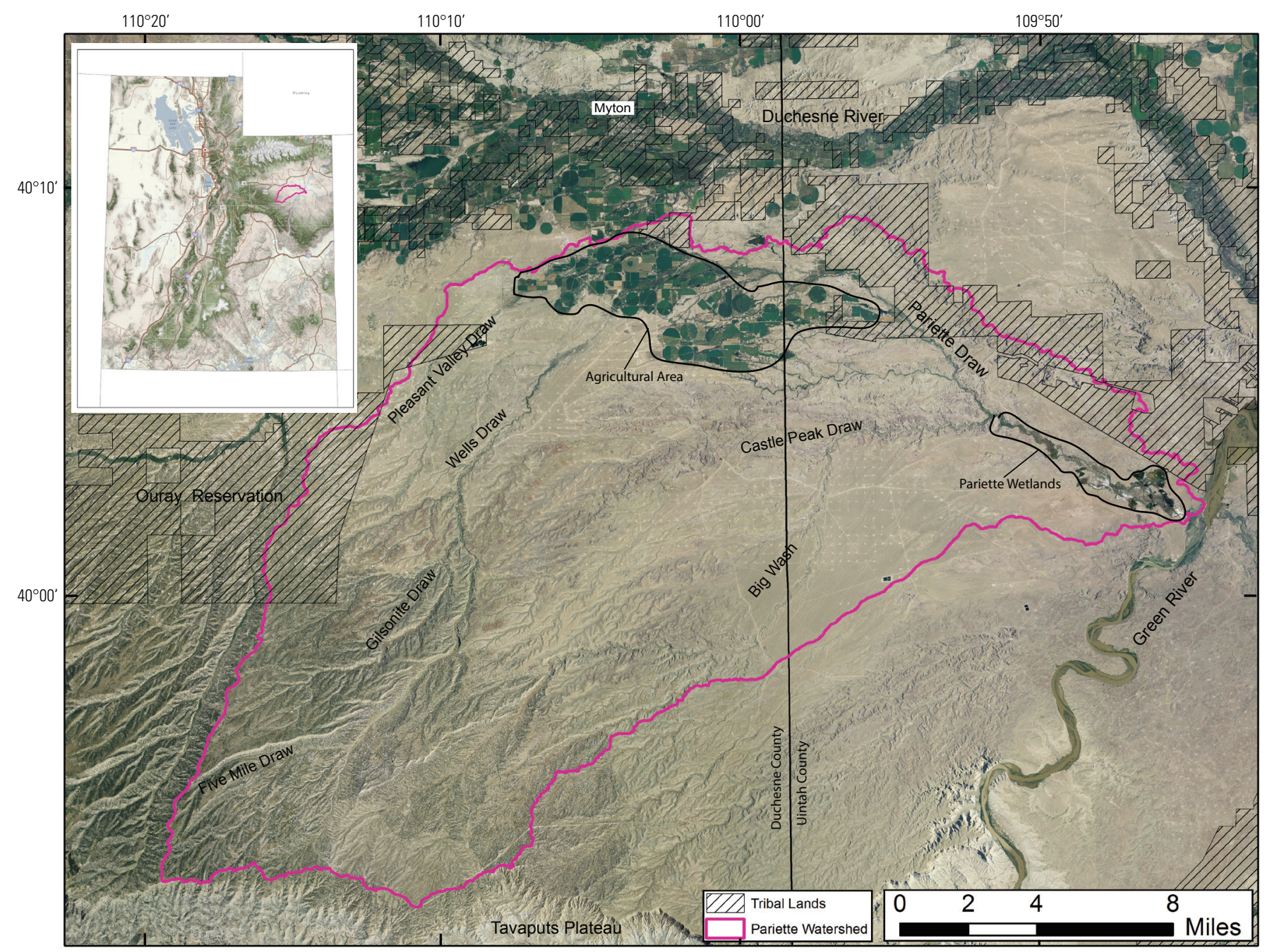

Figure 1. Location map for the Pariette Draw Watershed.

Wetlands, a series of BLM-managed wetlands located in the lower watershed just above the confluence with Green River (fig. 1). The wetlands provide habitat to abundant and diverse species of waterfowl. Because Se and B contamination can affect the health of waterfowl populations, the water quality in Pariette Draw is of major concern to wetland and wildlife managers.

In the northwestern portion of the upper watershed (Wells Draw and upper tributaries), the sandstone-limestone facies of the Tertiary Green River Formation underlie the lower Uinta Formation (fig. 2). This facies is a transitional unit which is light brown sandstone and siltstone interbedded with white to light gray marlstone and limestone. In the remainder of the watershed, the surface geology is the overlying lower Uinta Formation. The lower Uinta Formation consists of sandstone with minor conglomerates at its base and red and green claystone interbedded with sandstone at the top. Roll-front uranium deposits mined during the 1950 s are hosted by the upper sandstone members of the lower Uinta Formation. The largest concentration of mining activity was in Castle Peak Draw near gilsonite mines
(397 pounds of $\mathrm{U}_{3} \mathrm{O}_{8}$ from 1951 to 1954; Chenoweth, 1992). Formation of these roll-front deposits involved redox cycling in near-surface sandstone aquifers of fluvial or lacustrine origin similar to those deposited near the top of the lower Uinta Formation. The upper Uinta Formation, which crops out north of the study area, but has since been eroded in the watershed, is rich in bentonitic and swelling claystone likely derived from volcanic ash. The ash fall is thought to be the original source of uranium in the Pariette Draw roll-front deposits (Chenoweth, 1992). Volcanic ash is also known to contain selenium, vanadium, molybdenum, arsenic, and sulfur, elements that are often concentrated along with uranium in roll-front deposits that form as oxidized groundwater interacts with ash and solutes carried deeper into the aquifer (Harshman, 1974). When reducing conditions are encountered due to increased abundance of organic carbon, pyrite $\left(\mathrm{FeS}_{2}\right)$ or hydrogen sulfide $\left(\mathrm{H}_{2} \mathrm{~S}\right)$ gas, roll-front deposits form in halos around the reductant. Spatial separation of elements deposited is controlled by differential reduction potentials (Adler, 1974). 


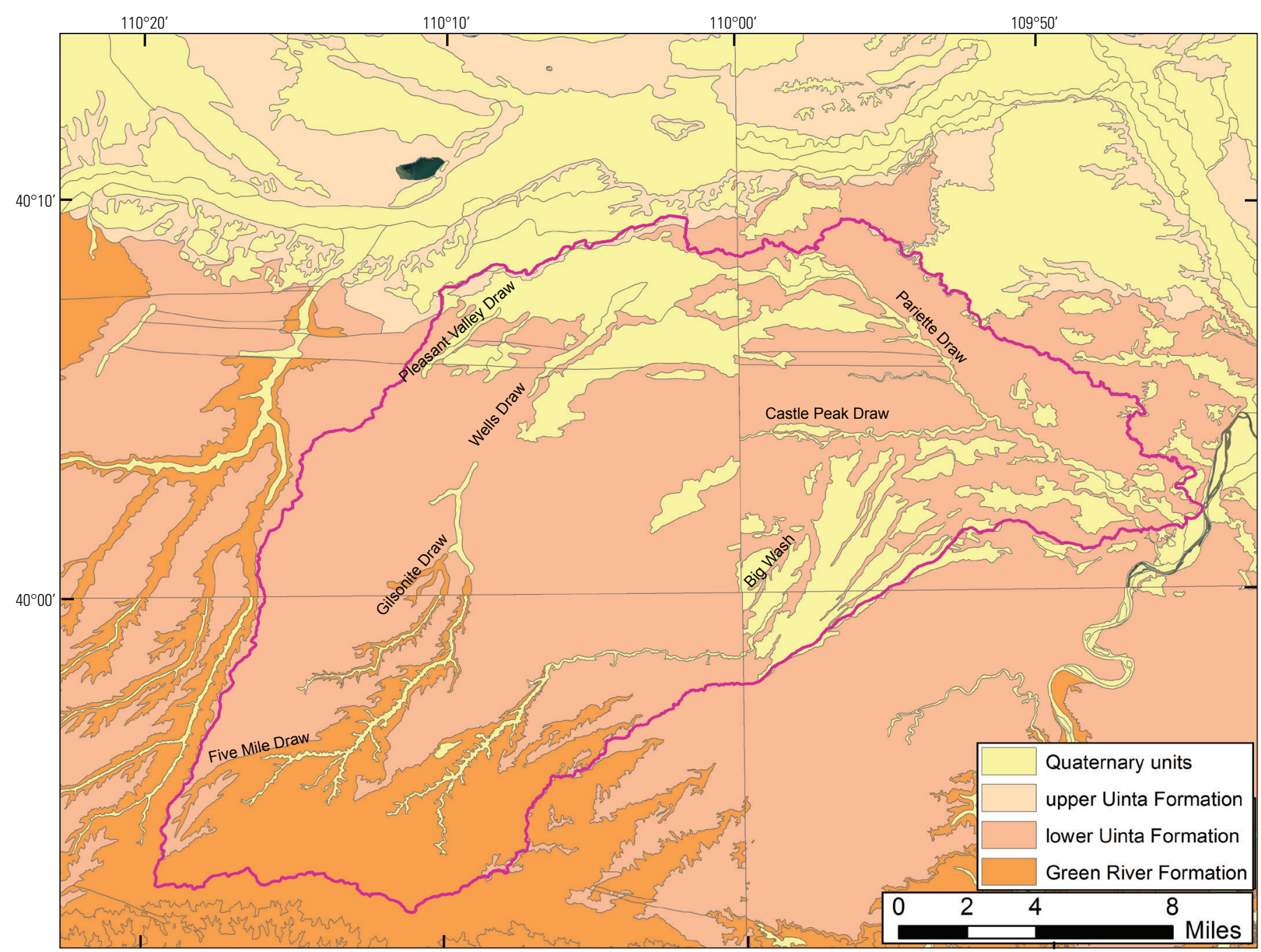

Figure 2. Simplified geologic map for the Pariette Draw Watershed (merged from four 30'x60' quadrangle geologic maps; Sprinkel, 2007; 2009; Utah Geologic Survey, 2009; Bryant, 2010). Magenta outline shows extent of the Pariette Draw Watershed (see location on fig. 1).

\section{Sampling}

Rock, soil, and surface and groundwater samples were collected throughout the Pariette Draw Watershed. Rocks were collected from 22 Green River Formation and lower Uinta Formation sites (table 1-1 in Appendix 1). Soil samples were collected at 69 sites (12 agricultural fields and 57 native soil sites). Water samples were collected from streams, canals, ponds, puddles in ephemeral streams, auger holes, springs, and seeps. Sample locations and number of samples collected at each site are in table 1.

Table 1. Number of samples collected and analyzed.

\begin{tabular}{lccc}
\hline $\begin{array}{c}\text { Sample } \\
\text { type }\end{array}$ & $\begin{array}{c}\text { Sample } \\
\text { sites }\end{array}$ & $\begin{array}{c}\text { Chemically } \\
\text { analyzed }\end{array}$ & $\begin{array}{c}\text { Mineralogically } \\
\text { analyzed }\end{array}$ \\
\hline Rock & 22 & 65 & 19 \\
Soil (bulk) & 69 & 508 & 25 \\
Extract & 69 & 610 & \\
Water & 35 & 68 & \\
\hline
\end{tabular}

\section{Rock and Soil Samples}

Rock sampling sites were selected to be representative of the three different geologic units in the watershed (upper Green River Formation and lower and upper portions of the lower Uinta Formation). Samples include upper Green River Formation limestones and sandstones, basal lower Uinta Formation sandstones, and upper lower Uinta Formation sandstones and interbedded red and green shales. White layers assumed to be volcanic ash were collected in all three units. Each sample was a grab sample composite across the lithologic unit of interest. When possible, the least-weathered rock was collected and any friable weathering crust was removed.

Soil was primarily collected by hand augering as deep as possible, up to a maximum of 9 feet. The soil was collected in 6-inch intervals and spread on a tarp, homogenized, and placed in plastic sample bags. In the laboratory, the bags were emptied onto plastic sheets and allowed to air dry. When dry, samples were disaggregated and sieved to less than $2 \mathrm{~mm}$ for 
analysis of bulk chemistry, mineralogy, and saturation paste extracts. The location of rock and soil samples are shown in figures $3 A$ and $B$.

\section{Water Samples}

Diverted irrigation and pond water, and stream water were collected as grab samples. Shallow groundwater was collected from auger holes in Pleasant Valley where the majority of agriculture occurs in the watershed. Samples from Pariette Draw below irrigated fields, standing water in ephemeral streambeds (puddles), shallow groundwater in wetland auger holes, and a natural spring were collected outside of Pleasant Valley. The location of water samples are shown in figure 4.

Water was collected with a syringe or a teflon bailer. Cation, anion, Se speciation, and bicarbonate splits were filtered $(0.45$ micrometer $[\mu \mathrm{m}])$ in the field. Cation samples were acidified with nitric acid. Sulfate isotope samples were filtered in the laboratory. All samples were refrigerated during transport and prior to analysis.

\section{Soil Bulk Density Samples}

Three-inch sections of steel pipe (1.25 inches [in.] in diameter) were used to collect the bulk density samples. The volume of the samplers was determined in the laboratory by stretching tape over one end and setting that end in liquid wax to assure a water-tight seal. The samplers were then filled with water and the volume of the water measured. For each soil density sample, the pipe was pushed into the soil with as little disturbance as possible. The pipe was withdrawn, collecting all the material from the hole and then transferred to a plastic sample bag. The hole depth was then measured to check for compression. For surface samples, the pipe was inserted vertically. A 12 in. (30 centimeter [cm]) hole was then dug where the surface sample was taken and the second interval was sampled horizontally into the side of the hole. The third interval was sampled vertically from the bottom of the hole. Twenty-three interval samples (in triplicate) were taken at 9 sites ( 2 agricultural fields and 7 native soil sites). In the laboratory, samples were dried in an oven at $105{ }^{\circ} \mathrm{C}$ for 2 hours and

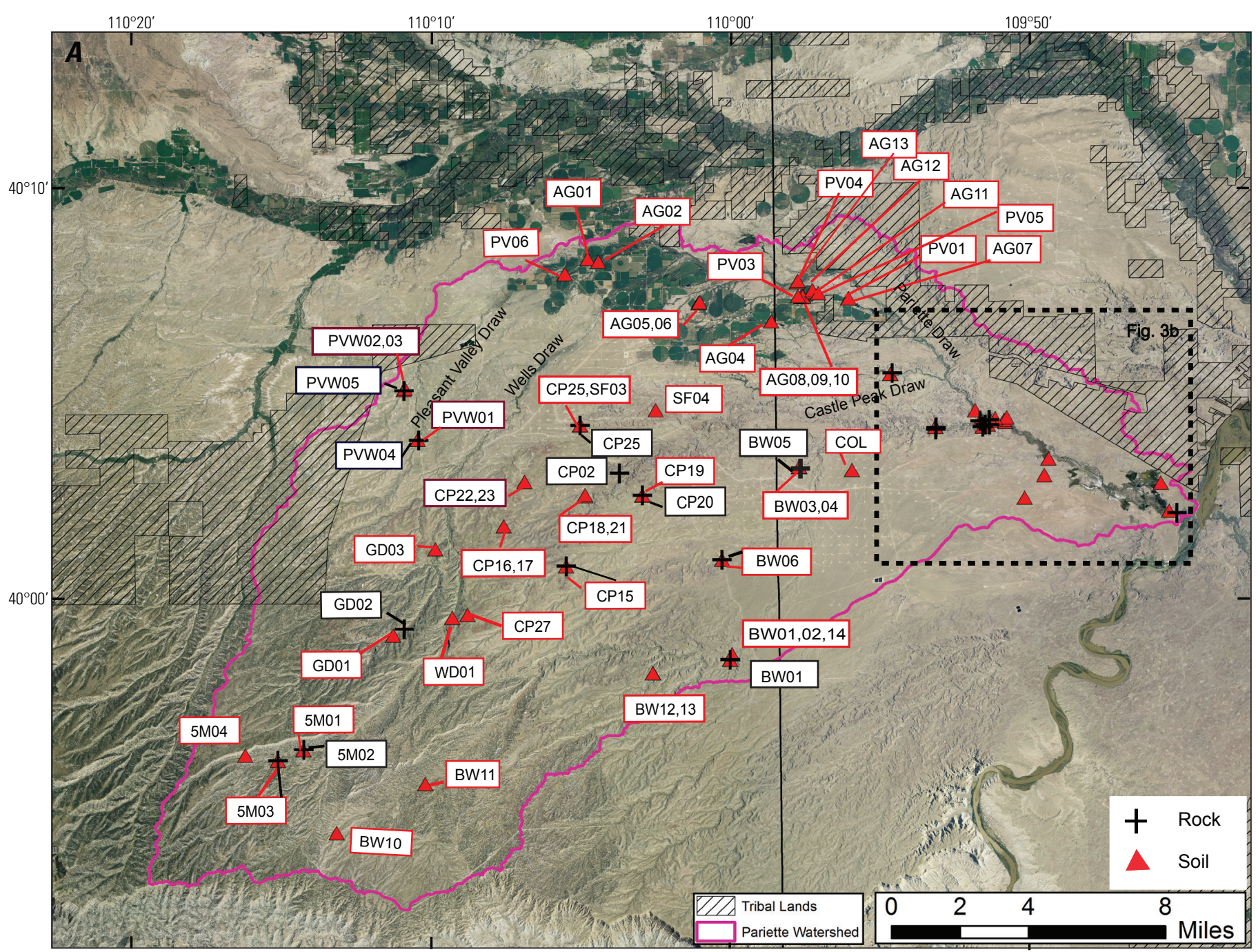

Figure 3. Map of rock and soil collection sites with $A$, showing entire watershed and $B$, a close up of the inset box in $3 A$. 
then weighed. Outlier measurements generally occurred for samples with small pebbles or voids. In the results, densities without these outliers are also reported.

\section{Extract Preparation}

Saturated paste extracts were prepared by mixing the soil or disaggregated shale samples (dried and ground portion of less than 2 millimeters [mm] material) into a smooth paste with a consistency comparable to that of pudding. According to U.S. Department of Agriculture methods, "At saturation, the soil glistens as it reflects light, flows slightly when the container is tipped, and slides freely and cleanly from a spatula except for those soils with high clay content" (U.S. Department of Agriculture, 2004, p. 283). There should be no free water on top of the sample. Each sample requires a different amount of water to be added to achieve the proper mixture, and the amount of water added is reflected in the percent saturation. That number is the amount of water added relative to the dry weight of the soil. For example, if a 200 gram $(\mathrm{g})$ soil sample requires 100 milliliter $(\mathrm{mL})$ of water to make a saturated paste, it has a 50 percent saturation. The $\mathrm{pH}$ is measured in the paste immediately prior to extraction of the solution. A sample of the paste is weighed, dried at $105^{\circ} \mathrm{C}$ overnight, and reweighed to establish saturation percent. The extract solution is removed by means of vacuum filtration using a $2 \mathrm{~mm}$ filter paper and analyzed for conductivity. The filtrate is then filtered through a $0.45 \mu \mathrm{m}$ filter and split for further chemical analyses. Percent saturation can be used to calculate extract concentrations to a dry-weight basis to compare data among samples:

$$
C d w \equiv(C e x \times(\% S / 100))
$$

where

$C d w \quad$ is extract concentration on a dry-weight basis;

Cex is concentration in filtrate; and

$\% S \quad$ is percent saturation.

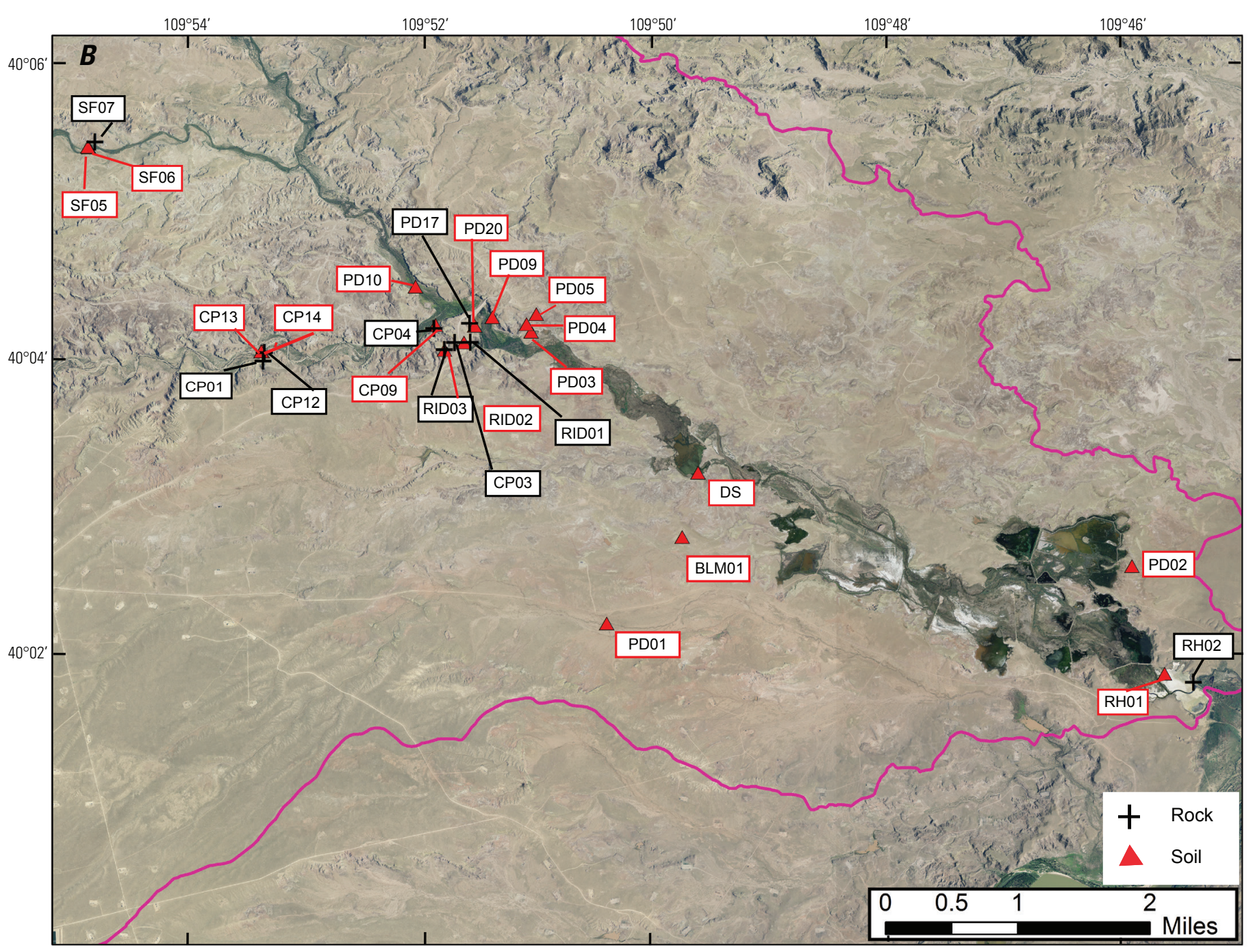

Figure 3. Map of rock and soil collection sites with $A$, showing entire watershed and $B$, a close up of the inset box in $3 A$. - Continued 


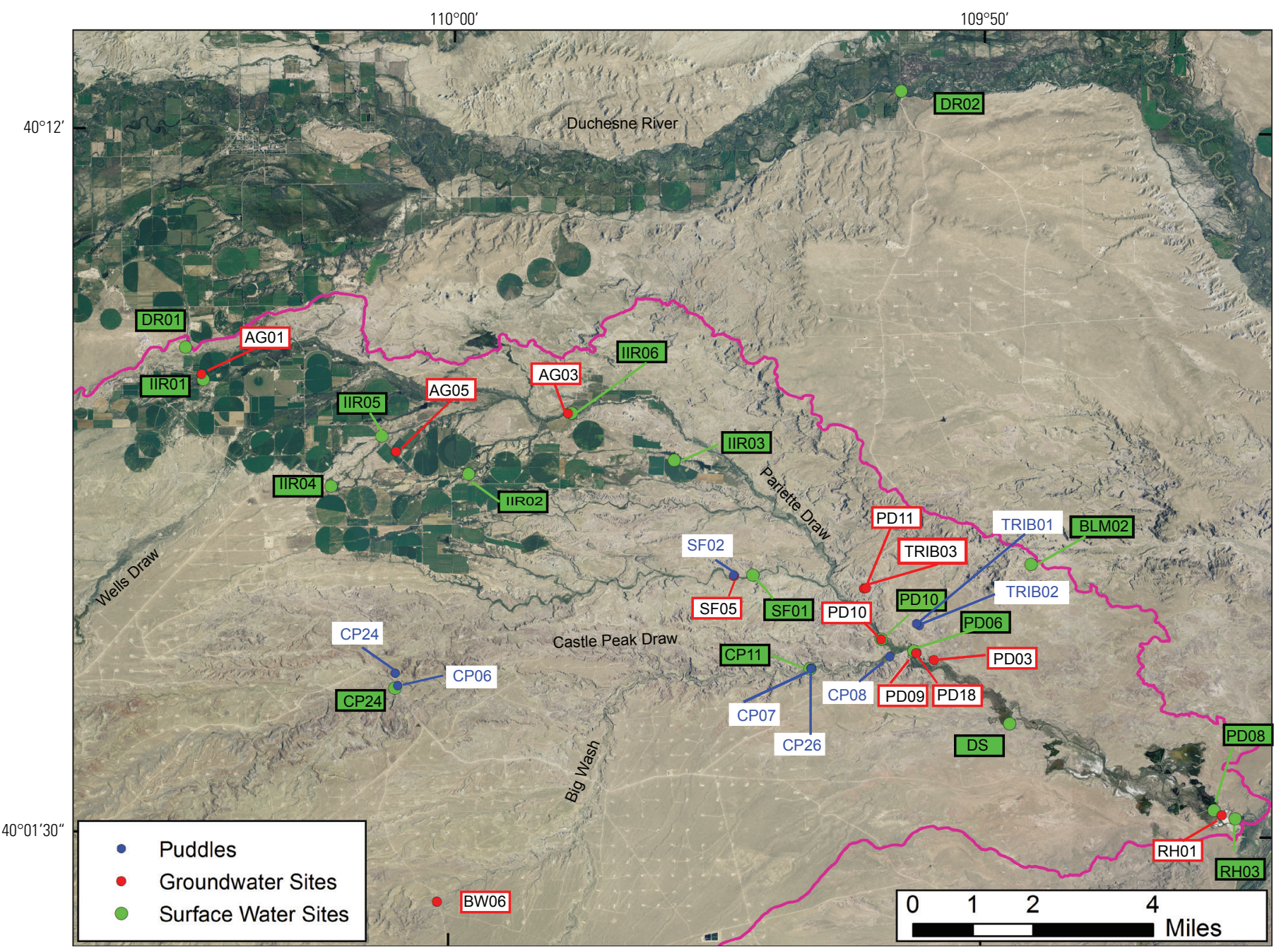

Figure 4. Map showing water collection sites.

\section{Analytical Methods}

\section{Chemical Analyses of Solid Samples, Soil Extracts, and Water}

SGS Mineral Services, Toronto, Canada, performed analyses of major and a suite of trace elements in the bulk rock and soil and also analyzed for additional trace elements on a selected split of rock and soil samples. Specialized analyses on solids such as istotopic analysis, mineralogy, and chemical anlyses of saturation paste extracts were performed in the U.S. Geological Survey laboratories, Denver, Colo. Table 2 summarizes the methods of analyses.

Water soluble salts and gypsum samples were placed in water and agitated for 30 minutes and then filtered (less than $0.45 \mu \mathrm{m})$. Gypsum samples were also heated in 6 normal hydrochloric acid (N HCL) warmed to approximately $30{ }^{\circ} \mathrm{C}$ and filtered. The $\mathrm{pH}$ of the water solution was adjusted to less than 2. Barium chloride (10 weight percent [wt\%]) solution was added to both the water and acid solutions until no further precipitation of barium sulfate $\left(\mathrm{BaSO}_{4}\right)$ occurred. The solutions were allowed to stand overnight and were then filtered. The $\mathrm{BaSO}_{4}$ collected was analyzed for the isotopic composition of sulfur and oxygen by methods in Kester and others (2011) and results reported as $\delta^{34} \mathrm{~S}$ and $\delta^{18} \mathrm{O} .{ }^{1}$ Oxygen compositions of the sulfate only were reported for samples extracted with water because of exchange of sulfate oxygen with water oxygen in acid extractions.

${ }^{1} \delta(\%)=\left(\mathrm{R}_{\text {sample }}-\mathrm{R}_{\text {standard }}\right) /\left(\mathrm{R}_{\text {standard }}\right) \times 1000$, where $\mathrm{R}$ is the ratio of ${ }^{34} \mathrm{~S}$ : ${ }^{32} \mathrm{~S}$ or ${ }^{18} \mathrm{O}:{ }^{16} \mathrm{O}$. The standard for sulfur is trolite from Cañon Diablo Meteorite (VCDT) and for oxygen, Standard Mean Oceaic Water (VSMOW). 
Table 2. Analytical methods.

\begin{tabular}{|c|c|c|c|}
\hline Analyses & Method & Abbreviation & Reference \\
\hline As, $\mathrm{Se}$ (extracts and water) & Hydride generation-atomic absorption spectroscopy & HY & 2 \\
\hline $\mathrm{C}_{\text {total }}$ (solids) & Combustion & Total & 1 \\
\hline $\mathrm{C}_{\mathrm{CO} 3}$ (solids) & Coulometric titration & Carbonate & 1 \\
\hline $\mathrm{C}_{\text {org }}$ (solids) & Difference $\left(\mathrm{C}_{\text {total }}-\mathrm{C}_{\mathrm{CO} 3}\right)$ & Organic & 1 \\
\hline Specific Cond. (extracts and water) & Electrial conductivity meter & $\mathrm{ECe}$ & 2 \\
\hline Major element (solids) & 4-acid digestion/inductively coupled plasma optical emission spectroscopy & OES & 1,3 \\
\hline Major element (extracts and water) & Inductively coupled plasma optical emission spectroscopy & OES & 2 \\
\hline $\mathrm{pH}$ & $\mathrm{pH}$ meter & $\mathrm{pH}$ & 2 \\
\hline Refractory trace element (solids) & Sinter/inductively coupled plasma mass spectroscopy & S MS & 1,4 \\
\hline Trace element (solids) & Inductively coupled plasma mass spectroscopy & $\overline{\mathrm{MS}}$ & 1,5 \\
\hline
\end{tabular}

${ }^{1}$ Analyzed in a commercial laboratory with quality assurance/quality control monitored by U.S. Geological Survey.

${ }^{2}$ Analyzed in U.S. Geological Survey laboratories (Taggart, 2002). Quality assurance/quality control internally monitored.

${ }^{3}$ Lithium metaborate fusion dissolved in dilute nitric acid.

${ }^{4}$ Sodium peroxide sinter at $450{ }^{\circ} \mathrm{C}$.

${ }^{5}$ Hydrofluoric-, nitric-, perchloric-, and hydrochloric acid digestion.

Mineralogy on a subset of rock and soil samples was determined by X-ray diffraction using methods from Eberl (2011). Samples were analyzed on a Scintag X-ray Diffractometer (XRD) from 5 to 65 degrees two-theta using $\mathrm{Cu} \mathrm{K}$-alpha radiation, with a step size of 0.02 degrees two theta, and a count time of two seconds per step using a scintillation counter. Quantitative mineralogy was calculated using RockJock (Eberl, 2011) and clay mineral identification was confirmed by collecting a less than $8 \mu \mathrm{m}$ fraction of each sample and preparing oriented slides. XRD scans were collected of the air-dried, ethylene glycolated, and two heat treatments $\left(400\right.$ and $550^{\circ} \mathrm{C}$ for 1 hour each) of the preparations ranging from 2 to 40 degrees two-theta using $\mathrm{Cu} \mathrm{K}$-alpha radiation, with a step size of 0.03 degrees two theta, and a count time of one second per step using a scintillation counter.

\section{Results}

Tabulated results are in the Appendix: table 1-2, water chemistry; table $1-3$, rock mineralogy; table $1-4$, rock chemistry; table 1-5, soil bulk density; table 1-6, soil mineralogy; table 1-7, bulk soil chemistry; table 1-8, sodium sinter/ICP-MS analyses on selected rock and soil samples; and table $1-9$, soil extract chemistry. Metadata in tables 1-10-1-14 include additional analytical information including elements with censored values (less than the lower limit of determination, which is defined as 5 times the standard deviation of the blank; Taggart, 2002), duplicate analyses, and laboratory and field blanks.

\section{References Cited}

Adler, H.H., 1974, Formation of uranium ore deposits, in, Formation of uranium ore deposits: Vienna, International Atomic Energy Agency, Athens, May 1974 [Proceedings] p.141-168.

Brantley, S., White, T.S., White, A.F., Sparks, D., Richter, D., Pregitzer, K., Derry, L., Chorover, J., Chadwick, O., April, R., Anderson, S., Amundson, R., 2006, Frontiers in exploration of the critical zone-Report of a workshop sponsored by the National Science Foundation (NSF), October 24-26, 2005: Newark, Del., 30 p.

Bryant, B., 2010, Geologic map of the east half of the Salt Lake City $1^{\circ} \times 2^{\circ}$ quadrangle (Duschene and Kings Peak $30^{\prime} \times 60^{\prime}$ quadrangles), Duchesne, Summit, and Wasatch counties, Utah, and Uinta county, Wyoming: Utah Geological Survey Miscellaneous Publication 10-1DM, http://files.geology.utah.gov/online/mp/mp10-01.pdf.

Chenoweth W.L., 1992, Uranium mining in the Uinta Basin, Utah, in, Fouch, T.D., Nuccio, V.F., Chidsey, T.C., eds., Hydrocarbon and mineral resources of the Uinta Basin, Utah and Colorado: Utah Geological Association Guidebook 20, p. 345-352.

Eberl, D.D., 2011, User's guide to RockJock-A program for determining quantitative mineralogy from powder $x$-ray diffraction data: U.S. Geological Survey Open-File Report 2003-78, 47 p., available at http://pubs.usgs.gov/ of/2003/of03-078. 
Harshman, E.N., 1974, Distribution of elements in some rolltype uranium deposits, in, Formation of uranium ore deposits: Vienna, International Atomic Energy Agency, Athens, May 1974 [Proceedings] p.169-183.

Kester, C.L., Rye, R.O., Johnson, C.A., Schwartz C., and Holmes, C., 2001, On-line sulfur isotope analysis of organic material by direct combustion-Preliminary results and potential applications: Isotopes in Environmental Health Studies, v. 37, p. 53-65.

Sprinkel, D. A., 2009, Interim geologic map of the Seep Ridge $30^{\prime} \times 60^{\prime}$ quadrangle, Uintah, Duchesne, and Carbon counties, Utah, and Garfield and Rio Blanco counties, Colorado: Utah Geological Survey Open-File Report 549DM, GIS data, scale 1:100,000, available at http://geology.utah.gov/online/ofr/ ofr-549.pdf.

Sprinkel, D.A., 2007, Interim geologic map of the Vernal $30^{\prime} \times 60^{\prime}$ quadrangle, Uintah and Duchesne counties, Utah, and Moffat and Rio Blanco counties, Colorado: Utah Geological Survey Open-File Report 506CD, scale 1:100,000, available at http://geology.utah.gov/maps/geomap/30x60/ pdf/ofr-506.pdf.

Taggart, J.E., Jr., ed., 2002, Analytical method for chemical analysis of geologic and other materials, U.S. Geological Survey Open-File Report 2002-223.
Tuttle, M.L.W., Fahy, J.W., Elliott, J.G., Grauch, R.I., Stillings, L.L, 2014, Contaminants from Cretaceous black shaleI. Natural weathering processes controlling contaminant cycling in Mancos Shale, southwestern United States, with emphasis on salinity and selenium: Applied Geochemisty, v. 46, 57-71.

Tuttle, M.L.W., Fahy, J.W., Elliott, J.G. Grauch, R.I., Stillings, L.L, 2014, Contaminants from Cretaceous black shaleII. Effect of geology, weathering, climate, and land use on salinity and selenium cycling, Mancos Shale landscapes, southwestern United States: Applied Geochemistry, v. 46, p. 72-84.

Utah Department of Environmental Quality (UDEQ), 2010, TMDLs for total dissolved solids, selenium, and boron in the Pariette Draw Watershed: Salt Lake City, Utah, Utah Department of Environmental Quality, Division of Water Quality, 116 p., http://www.deq.utah.gov/ProgramsServices/programs/ water/watersheds/docs/2010/11Nov/ParietteDrawTMD1Final.pdf.

U.S. Department of Agriculture, 2004, Soil survey laboratory methods manual: U.S. Department of Agriculture Soil Survey Investigations Report no. 42. ver. 4.0, p. 283.

Utah Geological Survey, 2003, Geologic map of the Price $30^{\prime} \times 60^{\prime}$ quadrangle, Carbon, Duchesne, Uintah, Utah, and Wasatch counties, Utah [digitized from the Weiss, Witkind, and Cashion (1990) U.S. Geological Survey Map I-1981], scale 1:100,000, available at http://geology.utah.gov/maps/geomap/30x60/ pdf/m-198.pdf. 


\section{Appendix 1}

(Available at http://dx.doi.org/10.3133/ofr20151132)

Table 1-1. Sample site designation, location, and description.

Table 1-2. Water chemical data.

Table 1-3. Rock mineralogical data.

Table 1-4. Rock chemical data.

Table 1-5. Bulk soil density data.

Table 1-6. Soil mineralogical data.

Table 1-7. Bulk soil chemistry.

Table 1-8. Bulk rock and soil chemistry (selected samples and selected elements by sodium peroxide sinter ICP-MS).

Table 1-9. Soil extract chemistry.

Table 1-10. Water analysis metadata.

Table 1-11. Rock analysis metadata.

Table 1-12. Bulk soil metadata.

Table 1-13. Soil extract metadata.

Table 1-14. Sulfate Isotope metadata.

Publishing support provided by:

Denver Publishing Service Center, Denver, Colorado

For more information concerning this publication, contact:

Director, USGS Crustal Geophysics and Geochemistry Science Center

Federal Center, Box 25046, MS 964

Denver, C0 80225

(303) 236-1373

Or visit the Crustal Geophysics and Geochemistry Science Center Web site at:

http://crustal.usgs.gov/

This publication is available online at:

http://dx.doi.org/10.3133/ofr20151132 

